\title{
Nomograms of the fetal neck circumference and area
}

\author{
Muhittin Eftal Avcl', İbrahim Polat ${ }^{2}$ \\ ${ }^{1}$ Perinatology Clinic, Nenebatun Obstetrics \& Gynecology Hospital, Erzurum, Turkey \\ ${ }^{2}$ Perinatology Clinic, Kanuni Sultan Siileyman Training and Research Hospital, İstanbul, Turkey
}

\begin{abstract}
Objective: We aimed to determine reference ranges and establish nomograms for fetal neck circumference and area in Turkish population.

Methods: A total of 696 women with singleton normal pregnancies were included in this prospective study and the fetal neck circumference and area measurements were conducted with the technique defined by Sherer et al. in 2007.

Results: The fetal neck circumference and area measurements were highly correlated with the weeks of gestation. The equations obtained for fetal neck circumference (FNC) and fetal neck area (FNA) were $\mathrm{FNC}=-0.0012 \mathrm{WG} 2+0.5312 \mathrm{WG}-1.9248\left(\mathrm{R}^{2}=0.8403 ; \mathrm{p}<0.01\right)$ and $\mathrm{FNA}=0.017 \mathrm{WG} 2-0.073 \mathrm{WG}\left(\mathrm{R}^{2}=0.8 ; \mathrm{p}<0.01\right)$, respectively.

Conclusion: This study helped us to establish nomograms of FNC and FNA in Turkish population for the second and third trimesters of gestation. We believe that these measurements could be a significant predictor for the determination of weeks of gestation.
\end{abstract}

Keywords: Area, circumference, fetal, neck, nomogram.

\section{Introduction}

Ultrasonographic scan is a significant component of antenatal care and fetal biometric measurements are the inseparable part of daily practice in modern obstetrics. ${ }^{[1,2]}$ Fetal biometry is the measurement of various areas of fetus and fetal anatomy. Each area of fetal structure can be imaged, but fetal head, abdomen and femur measurements are the most common measurements like crownrump length measurement during first trimester. ${ }^{[3]}$ The reliability of fetal biometric data for the estimation of fetal gestational age has been shown in the previous studies. ${ }^{[47]}$ Gottlieb and Galan argued that the combination

\section{Özet: Fetal boyun çevresi ve fetal boyun alanı nomogramı}

Amaç: Türk popülasyonunda fetal boyun çevresi ve fetal boyun alanı için referans değer aralıklarını tespit edip nomogram oluşturmayı amaçladık.

Yöntem: Bu prospektif çalışmaya, tekil, normal gebelikleri olan 696 gebe kadın dahil edilerek, 2007'de Sherer ve ark.'nın tanımladığı teknikle fetal boyun çevresi ve fetal boyun alanı ölçümleri yapildi.

Bulgular: Fetal boyun çevresi ve fetal boyun alanı ölçümleri gestasyonel hafta ile yüksek korelasyon göstermekte idi. Fetal boyun çevresi için; $\mathrm{FBC}=-0.0012 \mathrm{GH} 2+0.5312 \mathrm{GH}-1.9248\left(\mathrm{R}^{2}=0.8403\right.$; $\mathrm{p}<0.01)$ ve fetal boyun alanı için $\mathrm{FBA}=0.017 \mathrm{GH} 2-0.073 \mathrm{GH}\left(\mathrm{R}^{2}=\right.$ $0.8 ; \mathrm{p}<0.01)$ denklemleri elde edildi.

Sonuç: Bu çalışma bize gebeliğin ikinci ve üçüncü üç ayı için FBÇ ve FBA açısından Türk popülasyonunda nomogram oluşturulmasını sağlamıştır. Biz bu ölçümlerin gestasyonel haftanın tayininde önemli bir prediktör olabileceğini düşünmekteyiz.

Anahtar sözcükler: Alan, boyun, çevre, fetal, nomogram.

of fetal biometric data could increase the precision of fetal gestational age estimation and could decrease measurement variability among fetuses. ${ }^{[8]}$ In our study, we aimed to determine reference ranges and establish nomograms for transverse fetal neck circumference and area in Turkish population.

\section{Methods}

A total of 696 women, whose pregnancies were confirmed by the weeks of gestation, last menstrual period and early ultrasonography scan performed in the first
Correspondence: Muhittin Eftal Avc1, MD. Perinatology Clinic, Nenehatun Obstetrics \& Gynecology Hospital, Erzurum, Turkey. e-mail: eftal77@yahoo.com

Received: October 25, 2017; Accepted: December 05, 2017

Please cite this article as: Avcı ME, Polat İ. Nomograms of the fetal neck circumference and area. Perinatal Journal 2017;25(3):116-120.
Available online at: www.perinataljournal.com/20170253006 doi: $10.2399 /$ prn. 17.0253006 QR (Quick Response) Code: 
trimester and whose fetuses were between 14 and 40 weeks of gestation and had no anomaly, included in this prospective study. Multiple pregnancies, fetuses with anomaly and pregnancies found to have growth retardation were excluded from the study. Biparietal diameter (BPD), head circumference (HC), abdominal circumference (AC), femur length (FL) and humerus length (HL) were measured while axial fetal neck circumference (FNC) and fetal neck area (FNA) were measured three times. For each week of gestation (WG), 5th, 50th and 95th percentiles and standard deviation (SD) were calculated. FNC and FNA were measured with the technique defined by Sherer et al. ${ }^{[9]}$ in 2007 (Fig. 1). In this technique, fetal neck circumference and area are calculated on a plane where fetal neck is the widest and fetal neck is on the right angle towards cervical spines during transverse ultrasonographic scan. In our study, all measurements were done by the same operator (MEA) by using Voluson E6 ultrasound device (GE Healthcare, Little Chalfont, UK). The analysis of the data was done by the software SPSS 18.0 (SPSS Inc., Chicago, IL, USA). The reference value formulas, tables and graphics for FNC and FNA were created according to the method recommended by Royston and Wright. ${ }^{[10]}$

\section{Results}

For 696 pregnant women who met inclusion criteria, the mean age was $28.21 \pm 5.18$ (range: 19 to 40 ) years, median gravida was 3 (range: 1 to 10 ), and median parity was 1 (range: 0 to 9 ).

FNC was correlated with gestational age. The equation $\mathrm{FNC}=-0.0012 \mathrm{WG} 2+0.312 \mathrm{WG}-1.9248\left(\mathrm{R}^{2}=\right.$ $0.8403 ; \mathrm{p}<0.01)$ was obtained in the polynomial regression analysis (Fig. 2). The 5th, 50th and 95th percentiles and SD for FNC values measured for each week of gestation are shown in Table $\mathbf{1}$.

FNA was also correlated with gestational age and the equation $\mathrm{FNA}=0.017 \mathrm{WG} 2-0.073 \mathrm{WG} \quad\left(\mathrm{R}^{2}=0.8\right.$; $\mathrm{p}<0.01)$ was obtained in the polynomial regression analysis (Fig. 3). The 5th, 50th and 95th percentiles and SD for FNA values measured for each week of gestation are shown in Table 2.

All FNC and FNA measurements were performed by the same operator. The intraclass correlation coefficient was $0.91(\mathrm{p}<0.01)$ for FNC and $0.89(\mathrm{p}<0.01)$ for FNA. These values showed that the reproducibility of FNC and FNA measurements was high.

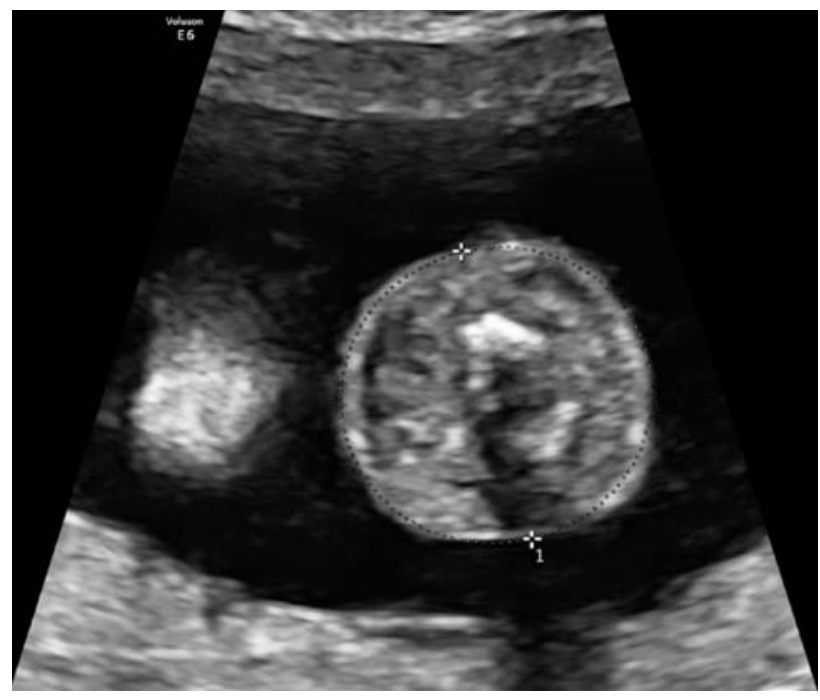

Fig. 1. Measurement technique for fetal neck circumference (FNC) and fetal neck area (FNA).

\section{Discussion}

The congenital anomalies related with fetal neck and fetal nape include the anomalies related with fetal aneuploidies [increased nuchal translucency (NT), cystic

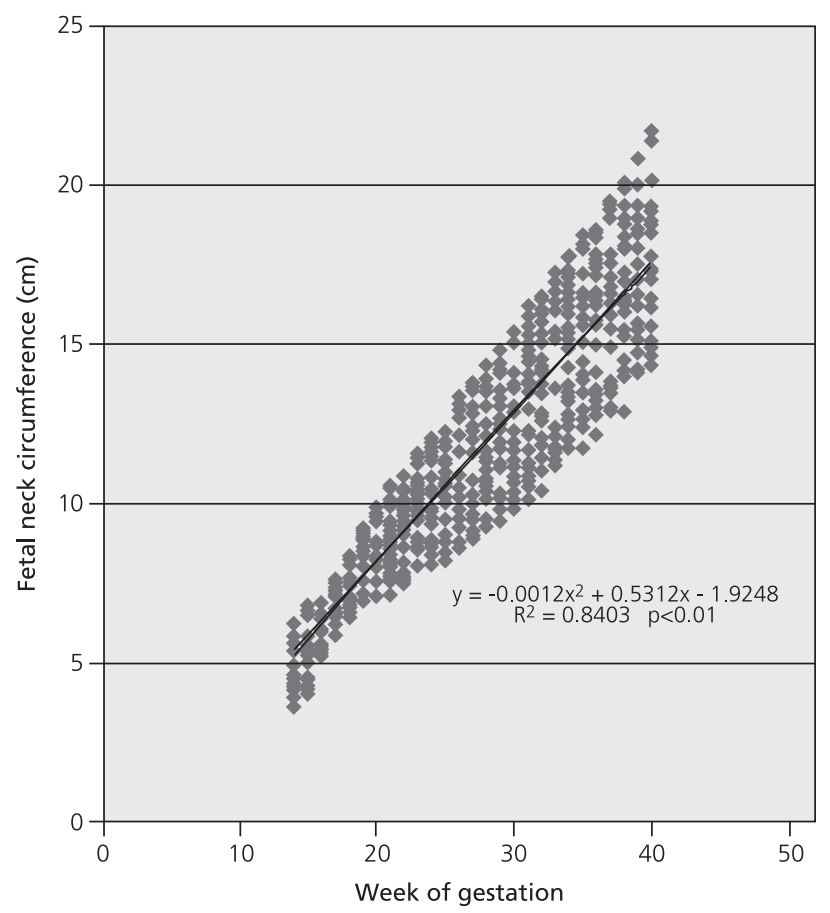

Fig. 2. Scatter graph for fetal neck circumference and week of gestation. 
hygroma, increased nuchal fold (NF)], ${ }^{[1]}$ primary structural anomalies (laryngeal cyst/stenosis, atresia, proximal esophageal atresia and bronchogenic cysts), ${ }^{[12,13]}$ functional anomalies (goiter) ${ }^{[14]}$ presence of embryological remnants (thyroglossal duct cysts and branchial cleft cysts) ${ }^{[15,16]}$ benign tumors (such as lymphangioma, ${ }^{[17]}$ hemangioma, ${ }^{[18]}$ hemangiopericytoma ${ }^{[19]}$ and teratoma, ${ }^{[20]}$ ) malign tumors (neuroblastoma ${ }^{[21]}$ and rhabdomyoma ${ }^{[22]}$ ), and many syndromes (Escobar syndrome, Yunis-Varon syndrome, Schinzel-Gledion syndrome $\left.{ }^{[23]}\right)$. Therefore, this area always has been an important area for the examination of fetal anatomy since the first trimester.

Moreover, evaluating many parameters to calculate gestational age will increase the reliability rather than evaluating a single sonographic parameter. ${ }^{[2,25]}$

Table 1. Reference ranges for fetal neck circumference.

\begin{tabular}{cccccc}
$\begin{array}{c}\text { Week of } \\
\text { gestation }\end{array}$ & $\begin{array}{c}\text { Patient } \\
\text { number }\end{array}$ & 5th $\mathbf{p}$ & Mean & 95 th $\mathbf{p}$ & SD \\
14 & 20 & 3.93 & 4.91 & 5.90 & 0.72 \\
15 & 19 & 4.20 & 5.32 & 6.73 & 0.78 \\
16 & 21 & 5.31 & 6.09 & 6.94 & 0.56 \\
17 & 24 & 5.90 & 6.74 & 7.54 & 0.55 \\
18 & 26 & 6.56 & 7.36 & 8.26 & 0.59 \\
19 & 25 & 7.01 & 8.15 & 9.17 & 0.75 \\
20 & 28 & 7.54 & 8.60 & 9.73 & 0.83 \\
21 & 35 & 7.61 & 9.09 & 10.56 & 1.09 \\
22 & 36 & 7.69 & 9.40 & 10.68 & 0.96 \\
23 & 33 & 8.08 & 9.91 & 11.49 & 1.04 \\
24 & 32 & 8.38 & 10.14 & 11.91 & 1.28 \\
25 & 26 & 8.63 & 10.27 & 13.15 & 1.25 \\
26 & 24 & 8.67 & 10.89 & 13.17 & 1.50 \\
27 & 22 & 8.99 & 11.11 & 13.69 & 1.71 \\
28 & 25 & 9.63 & 11.89 & 13.99 & 1.52 \\
29 & 25 & 9.85 & 12.25 & 14.41 & 1.49 \\
30 & 26 & 10.20 & 12.72 & 15.41 & 1.72 \\
31 & 24 & 10.26 & 13.22 & 15.88 & 1.96 \\
32 & 26 & 11.16 & 13.89 & 16.37 & 1.75 \\
33 & 25 & 11.40 & 14.57 & 17.20 & 2.18 \\
34 & 27 & 12.14 & 14.82 & 17.61 & 1.91 \\
35 & 24 & 12.42 & 15.27 & 18.19 & 2.01 \\
36 & 26 & 12.85 & 15.60 & 18.54 & 2.14 \\
37 & 24 & 13.14 & 16.10 & 19.44 & 2.20 \\
38 & 25 & 14.06 & 16.78 & 19.81 & 1.85 \\
39 & 24 & 14.24 & 17.04 & 20.71 & 1.99 \\
40 & 24 & 14.69 & 17.52 & 21.26 & 2.11 \\
\hline
\end{tabular}

p: percentile; SS: standard deviation.

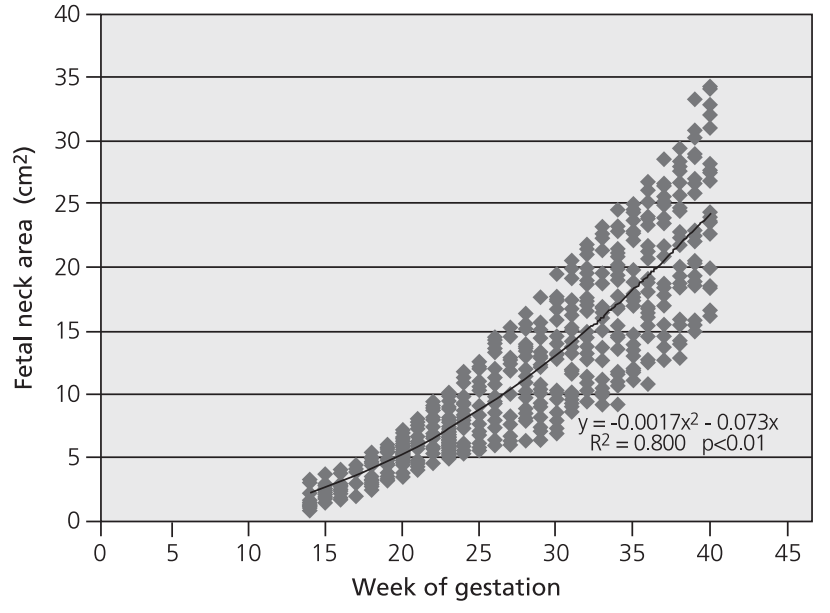

Fig. 3. Scatter graph for fetal neck area and week of gestation.

Table 2. Reference ranges for fetal neck area.

\begin{tabular}{|c|c|c|c|c|c|}
\hline $\begin{array}{l}\text { Week of } \\
\text { gestation }\end{array}$ & $\begin{array}{l}\text { Patient } \\
\text { number }\end{array}$ & 5th p & Mean & 95. $p$ & SD \\
\hline 14 & 20 & 0.86 & 1.86 & 3.11 & 0.74 \\
\hline 15 & 19 & 1.39 & 2.39 & 3.65 & 0.64 \\
\hline 16 & 21 & 1.58 & 2.82 & 3.92 & 0.81 \\
\hline 17 & 24 & 2.08 & 3.28 & 4.42 & 0.80 \\
\hline 18 & 26 & 2.62 & 4.09 & 5.45 & 0.96 \\
\hline 19 & 25 & 3.20 & 4.74 & 5.93 & 0.90 \\
\hline 20 & 28 & 3.64 & 5.62 & 7.27 & 1.10 \\
\hline 21 & 35 & 4.01 & 6.12 & 8.06 & 1.41 \\
\hline 22 & 36 & 5.04 & 7.02 & 9.26 & 1.40 \\
\hline 23 & 33 & 5.14 & 7.56 & 10.04 & 1.63 \\
\hline 24 & 32 & 5.56 & 8.19 & 10.28 & 1.92 \\
\hline 25 & 26 & 5.66 & 9.50 & 12.60 & 2.51 \\
\hline 26 & 24 & 5.98 & 10.38 & 14.31 & 2.69 \\
\hline 27 & 22 & 6.19 & 10.71 & 15.18 & 3.30 \\
\hline 28 & 25 & 6.65 & 11.19 & 15.41 & 2.79 \\
\hline 29 & 25 & 7.03 & 11.88 & 15.60 & 2.89 \\
\hline 30 & 26 & 7.26 & 12.32 & 17.71 & 3.87 \\
\hline 31 & 24 & 8.77 & 13.20 & 19.77 & 3.67 \\
\hline 32 & 26 & 9.61 & 15.51 & 21.25 & 3.68 \\
\hline 33 & 25 & 9.84 & 16.26 & 22.55 & 4.59 \\
\hline 34 & 27 & 10.65 & 16.78 & 23.11 & 4.31 \\
\hline 35 & 24 & 11.61 & 18.05 & 24.71 & 4.34 \\
\hline 36 & 26 & 12.54 & 19.07 & 25.82 & 4.40 \\
\hline 37 & 24 & 12.99 & 20.55 & 26.62 & 4.81 \\
\hline 38 & 25 & 13.97 & 21.76 & 28.24 & 4.95 \\
\hline 39 & 24 & 14.97 & 23.01 & 30.83 & 5.44 \\
\hline 40 & 24 & 16.30 & 25.16 & 33.93 & 5.66 \\
\hline
\end{tabular}

p: percentile; SS: standard deviation. 
The high correlation between the week of gestation and FNC and FNA measurements was shown in the studies of Hata et al. in 1988, Sherer et al. in 2007 and Abonyi et al. in 2017. ${ }^{[9,26,27]}$ In our study, FNC increased from $4.91 \pm 0.72$ at 14 weeks of gestation to $17.52 \pm 2.11$ at 40 weeks of gestation. FNA also increased from $1.86 \pm 0.74$ at 14 weeks of gestation to $25.16 \pm 5.66$ at 40 weeks of gestation.

Like Sherer et al. ${ }^{[9]}$ who conducted their studies on 720 pregnant women and successfully measured FNC and FNA values in each case, we also managed to measure FNC and FNA values in all 696 pregnant women who matched inclusion criteria. Hata et al. ${ }^{[26]}$ published these measurements in their study in 1988 and these measurements have become simpler with today's technology. In the literature, the interjudge reliability was evaluated only in the study of Abonyi et al. ${ }^{[2]}$ and the authors found a weak conformity among the operators. By now, there are three studies conducted with FNC and FNA nomograms. The reference ranges found by Sherer et et al. ${ }^{[9]}$ are quite similar to those found in the study of Hata et et al. ${ }^{[26]}$ up until 32 weeks of gestation, and the reference ranges found by Sherer et al. in the following weeks are systematically higher. They attributed this difference to the resolution quality which has been improved during the two decades between two studies. ${ }^{[9]}$ When Abonyi et al. also noticed the difference in reference ranges after 30-32 weeks of gestation, they argued that it was caused by the different populations rather than technological improvement. ${ }^{[27]}$ In general, the reference ranges in our study show similarity with the values found by Sherer et al. during entire pregnancy period.

Parikh et al. showed in the study published in 2014 that a single fetal growth curve could not be applied to all ethnic groups. ${ }^{[28]}$ Therefore, we established FNC and FNA nomograms for Turkish population and showed that these measurements are in high conformity with fetal gestational age and this measurement technique is highly reproducible (the intraclass correlation coefficient for FNC and FNA was 0.91 and 0.89 , respectively; $\mathrm{p}<0.01)$.

\section{Conclusion}

With this study, we managed to establish nomograms in Turkish population in terms of FNC and FNA for the second and third months of pregnancy, and we believe that these measurements could be a significant predictor for the determination of weeks of gestation.

Conflicts of Interest: No conflicts declared.

\section{References}

1. Munim S, Morris T, Baber N, Ansari Y, Azam SI. Growth charts of fetal biometry: a longitudinal study. J Matern Fetal Neonatal Med 2012;25:692-8.

2. Daniel-Spiegel E, Mandel M, Nevo D, Ben-Chetrit A, Shen O, Shalev E, et al. Fetal biometry in the Israeli population: new reference charts. Isr Med Assoc J 2016;18:40-4.

3. March MI, Warsof SL, Chauhan SP. Fetal biometry: relevance in obstetrical practice. Clin Obstet Gynecol 2012;55:281-7.

4. Babuta S, Chauhan S, Garg R, Bagarhatta M. Assessment of fetal gestational age in different trimesters from ultrasonographic measurements of various fetal biometric parameters. J Anat Soc India 2013;62:40-6.

5. Gjessing HK, Grøttum P. Accuracy of second trimester fetal head circumference and biparietal diameter for predicting the time of spontaneous birth. J Perinat Med 2007;35:350-1.

6. Kalish RB, Thaler HT, Chasen ST, Gupta M, Berman SJ, Rosenwaks Z, et al. First- and second-trimester ultrasound assessment of gestational age. Am J Obstet Gynecol 2004;191: 975-8.

7. Kumar K, Beg M, Babu C. Estimation of fetal gestational age in second and third trimesters from ultrasonographic measurements of different fetal biometric parameters. Indian J Clin Anat Physiol 2015;2:111-6.

8. Gottlieb AG, Galan HL. Nontraditional sonographic pearls in estimating gestational age. Semin Perinatol 2008;32:154-60.

9. Sherer DM, Sokolovski M, Dalloul M, Dib E, Pezzullo JC, Osho JA, et al. Nomograms of the fetal neck circumference and area throughout gestation. J Ultrasound Med 2007;26: 1529-37.

10. Royston P, Wright EM. How to construct 'normal ranges' for fetal variables. Ultrasound Obstet Gynecol 1998;11:20-38.

11. Kınay T, Kaplan M, Altay MM, Özdemirci Ş, Karadeniz S, Erol AO. Results of fetal anomaly screening performed at 11-14 weeks of gestation at a tertiary center. Perinatal Journal 2016;24:100-5.

12. Onderoglu L, Saygan Karamursel B, Bulun A, Kale G, Tuncbilek E. Prenatal diagnosis of laryngeal atresia. Prenat Diagn 2003;23:277-80.

13. Shulman A, Mazkerterth R, Zalel Y, Kuint J, Lipitz S, Avigad I, et al. Prenatal identification of esophageal atresia: the role of ultrasonography of functional anatomy. Prenat Diagn 2002; 22:669-74.

14. Uludoğan M, Şahinoğlu Z, Demirci F, Delikara MN, Kuyumcuoğlu U. İntrauterin fetal guatr. Perinatoloji Dergisi 1995;3:78-80. 
15. Foley DS, Fallat ME. Thyroglossal duct and other congenital midline cervical abnormalities. Semin Pediatr Surg 2006;15: $70-5$.

16. Horowitz E, Rabinerson D, Mashiach R, Shalev J, Meizner I. Ultrasound diagnosis of fourth branchial arch sinus at 22 weeks' gestation. Ultrasound Obstet Gynecol 2006;27:3202.

17. Arısoy R, Erdoğdu E, Pekin O, Demirci E, Çakar E, Tuğrul S. Cervical lymphangioma: a case report. Perinatal Journal 2013; 21:29-31.

18. Yoshida S, Kikuchi A, Naito S, Nakamura H, Hayashi A, Noguchi M, et al. Giant hemangioma of the fetal neck, mimicking a teratoma. J Obstet Gynaecol Res 2006;32:47-54.

19. Sepulveda W, Muhlhausen G, Flores X, Gutierrez J, Avila R. Giant hemangiopericytoma of the fetal neck: prenatal two- and three-dimensional sonographic findings. J Ultrasound Med 2003; 22:831-5.

20. Axt-Fliedner R, Hendrik HJ, Ertan K, Remberger K, Schmidt $\mathrm{W}$. Course and outcome of pregnancy with a giant fetal cervical teratoma diagnosed prenatally. Ultrasound Obstet Gynecol 2001;18:543-6.

21. Gorincour G, Dugougeat-Pilleul F, Bouvier R, LorthoisNinou S, Devonec S, Gaucherand P, et al. Prenatal presentation of cervical congenital neuroblastoma. Prenat Diagn 2003; 23:690-3.
22. O'Callaghan MG, House M, Ebay S, Bhadelia R. Rhabdomyoma of the head and neck demonstrated by prenatal magnetic resonance imaging. J Comput Assist Tomogr 2005;29:130-2.

23. Jones KL. Appendix 1: pattern of malformation in differential diagnosis by anomalies, 14: neck, thorax, and vertebrae. In: Smith's recognizable patterns of human malformation. 6th ed. Philadelphia, PA: Elsevier; 2006. p. 899.

24. Konje JC, Abrams KR, Bell SC, Taylor DJ. Determination of gestational age after the 24th week of gestation from fetal kidney length measurements. Ultrasound Obstet Gynecol 2002; 19:592-7.

25. Butt K, Lim K, Bly S; Diagnostic Imaging Committee. Determination of gestational age by ultrasound. J Obstet Gynaecol Can 2014;36:171-81.

26. Hata K, Hata T, Takamiya O, Kitao M. Ultrasonographic measurements of the fetal neck correlated with gestational age. J Ultrasound Med 1988;7:333-7.

27. Abonyi OE, Eze CU, Onwuzu SWI. Sonographic correlation of foetal neck circumference and area with gestational age among pregnant women in Port Harcourt, Nigeria. J Obstet Gynaecol 2017;37:1025-103.

28. Parikh LI, Nolan J 3rd, Tefera E, Driggers R. Fetal biometry: does ethnicity matter? J Matern Fetal Neonatal Med 2014; 27:500-4. 